\title{
Effect of enalapril and losartan on proteinuria in type 2 diabetic nephropathy patients
}

\author{
Rozina Hoque $^{1}$, Md. Sayedur Rahman ${ }^{1}$ and Masud Iqbal ${ }^{2}$ \\ ${ }^{1}$ Department of Pharmacology, Bangabandhu Sheikh Mujib Medical University, Shahbag, Dhaka; \\ ${ }^{2}$ Department of Nephrology, Sir Salimullah Medical College \& Mitford Hospital, Dhaka, Bangladesh. \\ e-mail: srkhasru@bdcom.com
}

\begin{abstract}
A prospective, open label, parallel group and randomized study was conducted to see the effect of enalapril and losartan on proteinuria in type 2 diabetic nephropathy patients. 18 patients (proteinuria $\geq$ $0.5 \mathrm{gm} /$ day and serum creatinine $\leq 3 \mathrm{mg} / \mathrm{dL}$ ) were selected and then randomly grouped to receive enalapril (5-40 mg/day, $n=10)$ and losartan $(25-200 \mathrm{mg} /$ day, $n=8)$ in increasing dose for 16 weeks. No statistically significant alteration in the urinary total protein, protein creatinine ratio, serum creatinine, estimated glomerular filtration rate, serum potassium and blood pressure was observed in any group. After attaining maximum dose (40 $\mathrm{mg}$ and $200 \mathrm{mg}$ respectively), enalapril group showed significant $(\mathrm{p}<0.04)$ reduction of protein creatinine ratio in comparison to losartan group. It may be concluded that $40 \mathrm{mg}$ enalapril or $200 \mathrm{mg}$ losartan are not sufficient to reduce proteinuria and blood pressure significantly in type 2 proteinuric diabetics with renal dysfunction although both drugs were well tolerated at high doses.
\end{abstract}

\section{Introduction}

Diabetes mellitus is a group of metabolic disorders characterized by chronic hyperglycemia with disturbances of carbohydrate, fat and protein metabolism resulting from defects in insulin secretion, insulin action, or both. It is a leading cause of heart disease, adult blindness, and amputations of the lower extremities ${ }^{1}$. Hypertension, retinopathy, nephropathy, neuropathy, peripheral vascular disease are the most frequent complications. Diabetic nephropathy is a chronic progressive kidney disease where there is gradual loss of renal function ultimately leading to end stage renal disease ${ }^{2}$.

In diabetes mellitus, local activation of the renin angiotensin system or increased intrarenal sensitivity to angiotensin II, especially angiotensin II receptor type 1 (ATIIR1) occurs. Blockade of renin angiotensin system with an angiotensin converting enzyme inhibitors, or angiotensin receptor blockers lead to a concordant rise in renal plasma flow and glomerular filtration rate, suggesting that the intrarenal renin angiotensin system is activated in diabetic patients ${ }^{3}$. Proteinuria has been considered an indicator of glomerular disease severity ${ }^{4}$. Proteinuria is strongly related to renal and cardiovascular morbidity, therefore its reduction is associated with improved outcome . $^{5}$ Agents that interfere with the renin angiotensin system to reduce proteinuria offer better renoprotection ${ }^{6}$.

In rat model, treatment with losartan at a dose 50 fold higher than those usually employed in experimental studies, arrested the progression of both glomerulosclerosis and interstitial expansion. This dose dependent effect of losartan is likely to be observed in human as well, since clinical studies showed that the human responses can be predicted with reasonable accuracy from animal experiments ${ }^{7}$. Data from another study suggested that additional reduction in proteinuria could be obtained by increasing the dose of candesartan from 32 to $96 \mathrm{mg}$ (3 times of maximal recommended dose) daily ${ }^{8}$. In a study with lisinopril, dose titration up to $40 \mathrm{mg}$, induced further reduction of residual proteinuria ${ }^{6}$. Previous studies in patients with advanced chronic heart failure showed that very high doses of enalapril (40 $\mathrm{mg}$ ) was well tolerated without significant additional adverse effects ${ }^{9}$.

The average antiproteinuric effect of renin angiotensin system blocking agents is usually observed at $50 \%$, both for angiotensin converting enzyme inhibitors and angiotensin receptor 
blockers ${ }^{10}$ and one of the strategies to optimize the response is dose titration of these agents ${ }^{11}$. In another study, no significant reduction in systolic and diastolic blood pressure was observed with increasing doses of enalapril ${ }^{12}$. In order to answer the confusion generated by these conflicting findings, the present study aims at demonstrating the effect of increasing doses of enalapril and losartan on reduction of proteinuria in type 2 diabetic nephropathy patients and to observe the tolerability of these two drugs at increasing doses.

\section{Materials and Methods}

This was a prospective, open label, parallel group, and randomized study, carried out during the period of July 2006 to June 2007. Hypertensive type 2 diabetic patients of age 45-75 years attending nephrology outpatient department of Bangladesh Institute of Research and Rehabilitation in Diabetes, Endocrine and Metabolic Disorders (BIRDEM) with serum creatinine $\leq 3.0 \mathrm{mg} / \mathrm{dL}, 24$ hours urinary total protein $\geq 0.5 \mathrm{~g}$ /day was taken as study population. Exclusion criteria were patients having uncontrolled blood pressure $(\geq 170 / 100 \mathrm{~mm}$ of $\mathrm{Hg}$ ) with multiple antihypertensive, major cardiovascular events within last 6 months (like recent myocardial infarction, coronary artery bypass grafting, stenting, cerebrovascular event), peripheral vascular disease, chronic heart failure, chronic liver disease, persistent hyperkalemia $(\geq 5.5$ $\mathrm{mmol} / \mathrm{L}$ ), anemia (hemoglobin $\leq 9 \mathrm{~g} / \mathrm{dL}$ ) and serum creatinine $>3 \mathrm{mg} / \mathrm{dL}$. Users of oral contraceptive pill, non-steroidal anti-inflammatory drugs and steroids were not included in the study. Outcome was measured by monitoring reduction in proteinuria to normal range $(\leq 0.15 \mathrm{~g} /$ day $)$. Total 18 patients were selected and on a random fashion, they were allowed to receive enalapril $(n=10)$ and losartan $(n=8)$ in two groups. Before starting study drugs, blood sugar was maintained at fasting $\leq 8$ $\mathrm{mmol} / \mathrm{L}$ and postprandial $\leq 11 \mathrm{mmol} / \mathrm{L}$.

Washout: Thereafter all previously taken antihypertensives and antiproteinuric drugs were gradually withdrawn in all patients within a period of 4-6 weeks. During tapering, blood pressure was maintained as $<170 / 100 \mathrm{mmHg}^{13-15}$.

Drug therapy: After washout period, patients received enalapril starting with $5 \mathrm{mg}$ and increasing to $40 \mathrm{mg}^{16-17}$ or losartan from 25 to $200 \mathrm{mg}^{18-20}$ doses in a period of 16 weeks. The primary end point of the study was blood pressure $<110 / 70$ $\mathrm{mmHg}$, serum potassium $>5.5 \mathrm{mmol} / \mathrm{L}$ or serum creatinine increasing $>30 \%$ in $1^{\text {st }}$ month.
Visit schedule: Each visit consisted of 2 consecutive days, $1^{\text {st }}$ day for sample collection and $2^{\text {nd }}$ day for blood pressure monitoring and dose increment. This process was maintained at 2 weeks interval throughout the trial period. At the beginning and then at 4 weeks interval patients were instructed to come to the hospital in fasting state on day of sample collection and to bring 24hours urine.

Blood collection: Blood samples were collected at beginning and then at certain drug doses such as in enalapril group after receiving 10, 20, 30 and 40 $\mathrm{mg}$ /day and in losartan group at 50, 100, 150 and $200 \mathrm{mg} /$ day. These samples were used to measure biochemical parameters. All the samples were collected in the fasting state. $10 \mathrm{~mL}$ of blood sample was drawn from cubital vein and taken in $100 \mu \mathrm{L}$ ethylenediamine tetraacetic acid (EDTA) containing test tube. Plasma was separated by centrifugation for $10 \mathrm{~min}$ at $3,000 \mathrm{rpm}$ at room temperature and stored at $-20^{\circ} \mathrm{C}$ until assay.

Urine: Aliquot from urine was stored at $-20^{\circ} \mathrm{C}$ until assay.

Clinical parameter: The blood pressure was measured at both sitting and standing position using a standard aneroid sphygmomanometer and appropriately sized cuff. Values were then averaged.

Laboratory methods: Blood sugar (fasting and postprandial) was estimated by glucose oxidase (GOD-PAP) method $^{21}$, serum creatinine was estimated by modified Jaffes method $^{22}$, serum electrolytes by ion selective method, liver function test - ALT by kinetic method. The urine sample was used to measure the urinary creatinine and 24hours urinary total protein by biuret method ${ }^{23}$. At the end of each active treatment period, 24-hours urinary total protein, urinary creatinine, serum creatinine, serum potassium was done. Protein/ creatinine ratio was calculated. Glomerular filtration rate was calculated using the CockroftGault formula ${ }^{24}$.

Tolerability: Tolerability of study treatment was assessed at each visit by enquiring about any incidence of adverse experiences and monitoring of blood pressure, serum potassium and creatinine.

Compliance: Compliance to the treatment was assessed by pill counting method.

Statistical methods: Continuous variables were compared by student's $t$ test and/or ANOVA. Values expressed as mean $\pm \mathrm{SD}$. All $\mathrm{p}$ values were from two-tailed test and $\mathrm{p}<0.05$ was considered statistically significant. Statistical analysis was performed using SPSS version 15 for Windows. 
Ethical clearance: The protocol was approved by the Ethical Review Committee of Bangabandhu Sheikh Mujib Medical University and BIRDEM. According to the approval granted, informed written consent after detail verbal explanation was taken from all the patients.

\section{Results}

In elanapril group, at baseline and after achieving $40 \mathrm{mg}$ enalapril urinary total protein was $1.65 \pm$ 0.83 vs. $1.17 \pm 0.90 \mathrm{~g} /$ day $(p=\mathrm{NS})$. The protein creatinine ratio and serum creatinine also remained unaltered during this period. Comparison of baseline estimated glomerular filtration rate was done with different dose groups and the difference was not statistically significant $(p=N S)$. Tolerability of enalapril at higher doses was seen by the changes in blood pressure and serum potassium level. Serum potassium remained unaltered after attaining $40 \mathrm{mg}$ enalapril. At baseline and after achieving $40 \mathrm{mg}$, the systolic blood pressure was $147 \pm 16.29$ vs. $146 \pm 22.58$ ( $p$ $=\mathrm{NS}$ ) and diastolic blood pressure was $83 \pm 11 \mathrm{vs}$. $81 \pm 11 \mathrm{mmHg}(p=\mathrm{NS})$ respectively (Table I).

Table I: Effect of enalapril on renal functions and blood pressure at increasing doses

\begin{tabular}{|c|c|c|c|c|c|c|}
\hline \multirow[t]{2}{*}{ Parameter } & \multirow[t]{2}{*}{ Baseline } & \multicolumn{4}{|c|}{ Dose of enalapril (mg/day) } & \multirow[b]{2}{*}{$\mathrm{p}$ value } \\
\hline & & 10 & 20 & 30 & 40 & \\
\hline Urinary total protein (g/day) & $1.65 \pm 0.83$ & $0.98 \pm 0.65$ & $1.22 \pm 0.79$ & $1.26 \pm 0.77$ & $1.17 \pm 0.90$ & 0.94 \\
\hline Protein creatinine ratio $(\mathrm{mg} / \mathrm{g})$ & $1.25 \pm 0.73$ & $0.98 \pm 0.71$ & $1.19 \pm 0.85$ & $1.72 \pm 1.14$ & $0.91 \pm 0.83$ & 0.99 \\
\hline Serum creatinine $(\mathrm{mg} / \mathrm{dL})$ & $1.9 \pm 0.5$ & $1.9 \pm 0.4$ & $1.8 \pm 0.4$ & $1.8 \pm 0.4$ & $1.8 \pm 0.4$ & 1.00 \\
\hline $\mathrm{eGFR}\left(\mathrm{mL} / \mathrm{min} / 1.73 \mathrm{~m}^{2}\right)$ & $42 \pm 13$ & $41 \pm 12$ & $42 \pm 11$ & $40 \pm 11$ & $40 \pm 11$ & 1.00 \\
\hline Serum potassium $(\mathrm{mmol} / \mathrm{L})$ & $4.6 \pm 0.5$ & $4.3 \pm 0.4$ & $4.5 \pm 0.3$ & $4.7 \pm 0.1$ & $4.6 \pm 0.3$ & 1.00 \\
\hline Systolic blood pressure $(\mathrm{mmHg})$ & $147 \pm 16$ & $139 \pm 15$ & $138 \pm 16$ & $143 \pm 20$ & $146 \pm 22$ & 1.00 \\
\hline Diastolic blood pressure $(\mathrm{mmHg})$ & $83 \pm 11$ & $82 \pm 10$ & $79 \pm 10$ & $80 \pm 10$ & $81 \pm 11$ & 0.99 \\
\hline
\end{tabular}

Data expressed as mean $\pm \mathrm{SD}$; eGFR $=$ estimated glomerular filtration rate; Analysis of variance (ANOVA) test was done to measure the significance of difference between different dose groups; $\mathrm{p}>0.05$ not significant

In losartan group, baseline and after achieving 200 mg losartan urinary total protein was $1.77 \pm 0.52$ vs. $2.18 \pm 1.75 \mathrm{~g} /$ day $(p=\mathrm{NS})$. Protein creatinine ratio and serum creatinine didn't change during this period. Tolerability of losartan at higher doses was seen by the changes in blood pressure and serum potassium level. Serum potassium remained unaltered after attaining $200 \mathrm{mg}$ losartan. At the baseline and after achieving $200 \mathrm{mg}$ losartan systolic blood pressure was $145 \pm 17$ vs.142 \pm 11 ; $\mathrm{mmHg}(\mathrm{p}=\mathrm{NS})$ and diastolic blood pressure $89 \pm 9$ vs. $84 \pm 10 ; \mathrm{mmHg}(p=\mathrm{NS})$ respectively (Table II).
Blood pressure and renal function parameters were compared between enalapril and losartan group after attaining maximum dose (40 and $200 \mathrm{mg}$ ) at 16 week (Table III). There was change in systolic and diastolic blood pressure, urinary total protein, estimated glomerular filtration rate, serum creatinine and serum potassium levels, however, the differences were not statistically significant. Protein creatinine ratio was the only parameter, where the difference was statistically significant ( $p$ $=0.04$ ).

Table II: Effect of losartan on renal functions and blood pressure at increasing doses

\begin{tabular}{|c|c|c|c|c|c|c|}
\hline \multirow[t]{2}{*}{ Parameter } & \multirow[t]{2}{*}{ Baseline } & \multicolumn{4}{|c|}{ Dose of losartan (mg/day) } & \multirow[b]{2}{*}{$\mathrm{p}$ value } \\
\hline & & 50 & 100 & 150 & 200 & \\
\hline Urinary total protein (g/day) & $1.77 \pm 0.52$ & $1.41 \pm 0.93$ & $1.68 \pm 1.04$ & $1.92 \pm 2.03$ & $2.18 \pm 1.75$ & 0.99 \\
\hline Protein creatinine ratio $(\mathrm{mg} / \mathrm{g})$ & $2.44 \pm 1.63$ & $1.04 \pm 0.33$ & $2.02 \pm 1.71$ & $2.76 \pm 2.97$ & $2.14 \pm 1.18$ & 1.00 \\
\hline Serum creatinine $(\mathrm{mg} / \mathrm{dL})$ & $1.7 \pm 0.4$ & $1.8 \pm 0.5$ & $1.7 \pm 0.3$ & $1.7 \pm 0.4$ & $1.7 \pm 0.3$ & 1.00 \\
\hline $\mathrm{eGFR}\left(\mathrm{mL} / \mathrm{min} / 1.73 \mathrm{~m}^{2}\right)$ & $46 \pm 9$ & $49 \pm 1$ & $45 \pm 3$ & $44 \pm 5$ & $44 \pm 5$ & 1.00 \\
\hline Serum $\mathrm{K}^{+}(\mathrm{mmol} / \mathrm{L})$ & $4.4 \pm 0.4$ & $4.5 \pm 0.4$ & $4.1 \pm 0.5$ & $4.5 \pm 0.5$ & $4.3 \pm 0.4$ & 1.00 \\
\hline Systolic blood pressure (mmHg) & $145 \pm 17$ & $136 \pm 10$ & $143 \pm 17$ & $141 \pm 15$ & $142 \pm 11$ & 1.00 \\
\hline Diastolic blood pressure (mmHg) & $89 \pm 9$ & $89 \pm 9$ & $86 \pm 11$ & $83 \pm 7$ & $84 \pm 10$ & 0.96 \\
\hline
\end{tabular}

Data expressed as mean \pm SD; eGFR = estimated glomerular filtration rate; Analysis of variance (ANOVA) test was done to measure the significance of difference between different dose groups; $\mathrm{p}>0.05$ not significant 
Table III: Comparison of enalapril (40 mg) and losartan (200 mg) groups

\begin{tabular}{lccc}
\hline Parameter & $\begin{array}{c}\text { Enalapril } \\
(\mathrm{n}=10)\end{array}$ & $\begin{array}{c}\text { Losartan } \\
(\mathrm{n}=8)\end{array}$ & $\begin{array}{c}\mathrm{p} \\
\text { value }\end{array}$ \\
\hline $\begin{array}{l}\text { Systolic blood pressure (mmHg) } \\
\text { Diastolic blood pressure }\end{array}$ & $146 \pm 22$ & $142 \pm 11$ & 0.71 \\
(mmHg) & $81 \pm 11$ & $84 \pm 10$ & 0.53 \\
Urinary total protein $(\mathrm{g} / \mathrm{d})$ & $1.2 \pm 0.9$ & $2.2 \pm 1.7$ & 0.17 \\
Protein creatinine ratio $(\mathrm{mg} / \mathrm{g})$ & $0.9 \pm 0.8$ & $2.1 \pm 1.2$ & $0.04^{*}$ \\
eGFR (mL/min/1.73m $\left.{ }^{2}\right)$ & $40 \pm 11$ & $45 \pm 2$ & 0.43 \\
Serum creatinine $(\mathrm{mg} / \mathrm{dL})$ & $1.8 \pm 0.5$ & $1.7 \pm 0.4$ & 0.71 \\
Serum potassium $(\mathrm{mmol} / \mathrm{L})$ & $4.6 \pm 0.4$ & $4.4 \pm 0.4$ & 0.24 \\
\end{tabular}

$\begin{array}{llll}\text { Alanine aminotransferase (U/L) } & 20.40 \pm 3.91 \quad 21.66 \pm 13.42 \quad 0.88\end{array}$

Data expressed as mean \pm SD; eGFR $=$ Estimated glomerular filtration rate; *=Significant; Unpaired ' $t$ ' test was done to measure the significance of difference between the two groups; $\mathrm{p}>0.05$ not significant; $\mathrm{p}<0.05$ significant

\section{Discussion}

In the present study, enalapril and losartan didn't significantly reduce proteinuria and blood pressure even at higher doses. In a previous study, increasing doses of enalapril could not produce any significant effect on systolic and diastolic blood pressure $^{12}$. The similar effect of enalapril on blood pressure in the present study indicates the possibility of insufficient suppression of renin angiotensin aldosterone axis, which might be responsible for insignificant decrease in proteinuria or blood pressure. That study also revealed the tolerability of enalapril up to $40 \mathrm{mg}$ once daily dose ${ }^{12}$, which is reconfirmed in the present study.

Brunner-La Rocca et al., (1999) found that serum $\mathrm{K}^{+}$and serum creatinine were slightly higher at high dose $[40 \mathrm{mg} /$ day (4 times the recommended dose)] than lower dose (10 mg/day) of enalapril; however ACEI therapy was not required to be discontinued in these patients ${ }^{17}$. An increase in enalapril dose did not lead to hyperkalemia. Serious adverse events (i.e. worsening of chronic heart failure, anuria and serious arrhythmia) tended to be more common after downward than after upward titration of enalapril.

In the present study, no significant decrease is observed in proteinuria or blood pressure after attaining maximum dose (200 $\mathrm{mg})$ of losartan. Nevertheless, in a previous study, dose of losartan while increased from 50 to $150 \mathrm{mg}$ among macroproteinuric patients with normal renal function observed maximal antiproteinuric effect at $100 \mathrm{mg}$ dose $^{13}$. Patient characteristics may be an influencing factor for non-responsiveness in the present study, where the subjects included have mild to moderate renal failure with heavy proteinuria. Most of the studies, which showed effective reduction of blood pressure and proteinuria were conducted on normotensive and/or microalbuminuric group of patients ${ }^{14-15}$. It might be that advanced renal failure patients with proteinuria may not respond to increasing doses of enalapril or losartan, which corresponds with findings of another study with increasing doses of enalapril (5 to $40 \mathrm{mg}$ ) in macroproteinuric patients with advanced renal insufficiency of variable etiologies $^{12}$. In that study, blood pressure and proteinuria didn't change significantly in both high and low dose groups.

Huo et al., (2007) undertook a study with losartan starting with $50 \mathrm{mg}$ and then increasing to $200 \mathrm{mg}$ in proteinuric nephropathy patients and found significant reduction in blood pressure and proteinuria $^{20}$. But in their study, to control blood pressure, simultaneous antihypertensive drugs were used. In the present work, no other antihypertensive drug was added throughout the study period, to ascertain the exclusive antiproteinuric effect of enalapril and losartan. It may be possible that antihypertensive drugs in that study reduced blood pressure significantly which influenced the proteinuria reduction to a significant level unlike the presenting one.

Woo et al., (2000) carried out a study in nondiabetic proteinuric subjects with renal dysfunction using $10 \mathrm{mg}$ enalapril and $100 \mathrm{mg}$ $\operatorname{losartan}^{25}$. They found that blood pressure or proteinuria was reduced only in $30 \%$ to $50 \%$ patients. The non-responder patients were those who had heavy proteinuria ( $>2 \mathrm{~g} /$ day) and more advanced renal dysfunction (serum creatinine $>2.5$ $\mathrm{mg} / \mathrm{dL}$ ). Characteristics of non responder patients in that study was similar to the patients included in the presenting work indicating combination of heavy proteinuria with advanced renal impairment may be less or non responsive to angiotensin converting enzyme inhibitors or angiotensin receptor blocker even at higher doses.

Although, enalapril and losartan didn't produce the expected antihypertensive and antiprotienuric effect at high doses, renal function was unaltered without any significant increase in serum creatinine and potassium levels. Tolerability at high dose observed in this study is consistent with one study conducted with losartan ${ }^{13}$ and conflicting with another study conducted with enalapril $^{17}$.

It is known that, these drugs, even when do not reduce proteinuria or blood pressure significantly, may provide the additional renoprotection with higher doses. Higher drug doses can reduce nephrotoxic components like TGF $\beta^{13}$, connective tissue growth factor ${ }^{18}$, and inflammatory mediators like cytokines ${ }^{26}$. 
It may be concluded that enalapril (40 mg) or losartan $(200 \mathrm{mg})$ even in high doses alone are not sufficient to reduce proteinuria or blood pressure significantly in type 2 proteinuric diabetics with renal dysfunction. Though the antiproteinuric effect was not significant, enalapril appears to have more antiproteinuric effect than losartan as reflected in protein creatinine ratio. Notably, these high doses of both drugs were well tolerated in this group of patients which was evidenced by unaltered clinical and biochemical parameters.

\section{References}

1. Anderson RN. Deaths: Leading causes for 1999. Natl Vital Stat Rep. 2001; 49: 1-87.

2. UK Prospective Diabetes Study Group. Tight blood pressure control and risk of macrovascular and microvascular complications in type 2 diabetes: UKPDS 38. BMJ. 1998; 317: 703-13.

3. Hollenberg NK, Price DA, Fisher ND, Lansang MC, Perkins B, Gordon MS, Williams GH, Laffel LM. Glomerular hemodynamics and the renin-angiotensin system in patients with type 1 diabetes mellitus. Kidney Int. 2003; 63: 172-78.

4. Campese VM, Bianchi S, Bigazzi R. Is microalbuminuria a predictor of cardiovascular and renal disease in patients with essential hypertension? Curr Opin Nephrol Hypertens. 2000; 9: 143-47.

5. Schmieder RE, Klingbeil AU, Fleischmann EH, Veelken R, Delles C. Additional antiproteinuric effect of ultrahigh dose candesartan: A double-blind, randomized, prospective study. J Am Soc Nephrol. 2005; 16 : 3038-45.

6. Vogt L, Navis G, de Zeeuw D. Individual titration for maximal blockade of renin-angiotensin system in proteinuric patients: A feasible strategy? J Am Soc Nephrol. 2005; 16 (Suppl 1): S53-57.

7. Sweet CS, Nelson EB. How well have animal studies with losartan predicted responses in human? J Hypertens. 1993; 11 (Suppl): S63-67.

8. Weinberg AJ, Zappe DH, Ashton M, Weinberg MS. Safety and tolerability of high-dose angiotensin receptor blocker therapy in patients with chronic kidney disease: A pilot study. Am J Nephrol. 2004; 24: 340-45.

9. Massie BM, Armstrong PW, Cleland JG, Horowitz JD, Packer M, Poole-Wilson PA, Rydén L. Toleration of high doses of angiotensin-converting enzyme inhibitors in patients with chronic heart failure: Results from the ATLAS trial. Arch Intern Med. 2001; 161: 165-71.

10. Gansevoort RT, de Zeeuw D, de Jong PE. Is the antiproteinuric effect of ACE inhibition mediated by interference in the renin angiotensin system? Kidney Int. 1994; 45: 861-67.

11. Laverman GD, Navis G, Henning RH, de Jong PE, de Zeeuw D. Dual renin-angiotensin system blockade at optimal doses for proteinuria. Kidney Int. 2002; 62: 1020-25.

12. Tang WH, Vagelos RH, Yee Y-G, Benedict CR, Willson $\mathrm{K}$, Liss CL, LaBelle $\mathrm{P}$, Fowler MB.
Neurohormonal and clinical responses to high versus low-dose enalapril therapy in chronic heart failure. J Am Coll Cardiol. 2002; 39: 70-78.

13. Andersen S, Rossing P, Juhi TR, Deinum J, Parving HH. Optimal dose of losartan for renoprotection in diabetic nephropathy. Nephrol Dial Transplant. 2002; 17: 1413-18.

14. Zandbergen AA, Baggen MG, Lamberts SW, Bootsma $\mathrm{AH}$, de Zeeuw D, Ouwendjik RJ. Effect of losartan on microalbuminuria in normotensive patients with type 2 diabetes mellitus: A randomized clinical trial. Ann Intern Med. 2003; 139: 90-96.

15. Lacourcière Y, Bélanger A, Godin C, Halle JP, Ross S, Wright N, Marion J. Long-term comparison of losartan and enalapril on the kidney function in hypertensive type 2 diabetics with early nephropathy. Kidney Int. 2000; 58: 762-69.

16. Elung-Jensen T, Heisterberg J, Sonne J, Strndgaard S, Kamper AL. Enalapril dosage in progressive chronic nephropathy: A randomized, controlled trial. Eur J Clin Pharmacol. 2005; 61: 87-96.

17. Brunner-La Rocca HP, Weilenmann D, Kiowski W, Maly FE, Follath F. Plasma level of enalaprilat in chronic therapy of heart failure: Relationship to adverse events. J Pharmacol Exp Ther. 1999; 289: 565-71.

18. Andersen S, van Nieuwenhoven FA, Tarnow L, Rossing P, Rossing K, Wieten L, Goldschmeding R, Parving $\mathrm{HH}$. Reduction of urinary connective tissue growth factor by losartan in type 1 patients with diabetic nephropathy. Kidney Int. 2005; 67: 2325-29.

19. Gradman AH, Arcruri KE, Goldberg AI, Ikeda LS, Nelsen EB, Snavely DB, Sweet CS. A randomized, placebo-controlled, double-blind, parallel study of various doses of losartan potassium compared with enalapril maleate in patients with essential hypertension. Hypertension 1995; 25: 1345-50.

20. Hou FF, Xie D, Zhang X, Chen PY, Zhang WR, Liang M, Guo ZJ, Jiang JP. Renoprotection of optimal antiproteinuric dose (ROAD) study: A randomized controlled study of benazepril and losartan in chronic renal insufficiency. J Am Soc Nephrol. 2007; 18: 188998.

21. Trinder P. Determination of blood glucose using 4amino phenazone as oxygen acceptor. J Clin Pathol. 1969; 22: 246.

22. Bartles H, Böhmer M. Micro-determination of creatinine. Clin Chim Acta 1971; 32: 81-85.

23. Weichselbaum TE. Biuret protein assay. Am J Clin Pathol. 1946; 10 (Suppl): 40.

24. Krimholtz M, Karalliedde J, Thomas S, Bilous R, Viberti G. Targeting albumin excretion rate in the treatment of the hypertensive diabetic patient with renal disease. J Am Soc Nephrol. 2005; 16: S42-47.

25. Woo KT, Lau YK, Wong KS, Chiang GS. ACEI/ATRA therapy decreases proteinuria by improving glomerular perm selectivity in IgA nephritis. Kidney Int. 2000; 58: 2485-91.

26. Fujihara CK, Velho M, Malheiros DM, Zatz R. An extremely high dose of losartan affords superior renoprotection in the remnant model. Kidney Int. 2005; 67: 1913-24. 